J. Lake Sci. (湖泊科学), 2011, 23(5): 719-724

http: //www. jlakes.org. E-mail: jlakes@niglas.ac.cn

(C) 2011 by Journal of Lake Sciences

\title{
湖泊缓冲带范围划定的初步研究一一太湖为例
}

胡小贞 ${ }^{1}$, 许秋瑾 $^{1 * *}$, 蒋丽佳 $^{1}$, 董思远 ${ }^{1}$, 金丹越 $^{2}$

(1: 中国环境科学研究院湖泊工程技术中心, 北京 100012)

( 2 : 北京锡兰石环境工程公司, 北京 100012)

\begin{abstract}
摘 要: 本文以我国大型浅水湖泊一一太湖为例, 通过资料调研、地形勘测、现场调查、研究与分析等手段, 开展太湖缓冲 带范围划定研究. 在文献调研国内外河湖缓冲带研究的基础上, 确定太湖缓冲带宽度为 $2 \mathrm{~km}$ 不等. 其中环湖大堤及湖岸 线为缓冲带的下边界, 以下边界线向陆地扩展 $2 \mathrm{~km}$ 不等为基准, 考虑标识物 (村落、山体、公路) 及区域差异等原则, 确定 缓冲带的上边界. 按边界土地利用类型划分, 太湖缓冲带可分为村落农田型、公路型和山体型三种典型类型. 村落农田型 缓冲带以距湖岸 $2.0 \mathrm{~km}$ 左右的行政村为上边界, 公路型缓冲带以距离湖岸 $1.5-2.0 \mathrm{~km}$ 与太湖湖岸平行的公路为上边 界, 山体型缓冲带以山体山脊作为上边界. 按此原则与方法, 基于 1:5000 地形图, 以 Auto CAD 为工具, 计算出太湖缓冲带 总长度为 $382.75 \mathrm{~km}$, 总面积约为 $452.31 \mathrm{~km}^{2}$.
\end{abstract}

关键词: 湖泊;缓冲带;范围划定;太湖

\section{A preliminary study on demarcation limits of lake buffer zones: a case study of Lake Taihu}

\author{
HU Xiaozhen ${ }^{1}$, XU Qiujin ${ }^{1}, J_{A N G}$ Lijia $^{1}$, DONG Siyuan ${ }^{1} \&$ JIN Danyue ${ }^{2}$ \\ ( 1 :Lake Engineering Research Center, Chinese Research Academy of Environmental Sciences, Beijing 100012, P. R. China) \\ (2: Beijing Ceylon Stone Environmental Engineering Company, Beijing 100012, P. R. China)
}

\begin{abstract}
Taking Lake Taihu which was the third largest shallow lake in China as an example, we researched the demarcation of buffer zone on the basis of information collection, topographic survey and field investigation. On domestic and international literatures about buffer zones of lakes, we preliminarily defined approximately $2 \mathrm{~km}$ wide as the width of Lake Taihu buffer zone. Considering the principles of land markers (villages, roads, mountains) and regional differences of regulations and planning, we defined the upper and lower boundaries of the buffer zone. The lower boundary was at the lake shoreline or levees around the lake. The upper boundary was at approximately $2 \mathrm{~km}$ from the lower boundary. According to land use types, there were three typical types of villages, roads and mountains in Lake Taihu buffer zone. The upper boundary at village area was divided by the administrative villages about $2.0 \mathrm{~km}$ from the lakeshore, and was divided by roads when the roads are paralleled with the lake shores. At mountain area, the upper boundary was divided by mountain ridges. On the 1:5000 topographic maps, we calculated $382.75 \mathrm{~km}$ in total length and $452.31 \mathrm{~km}^{2}$ in the total area of Lake Taihu buffer zone by means of Auto CAD software.
\end{abstract}

Keywords: Lake; buffer zone; boundary division; Lake Taihu

湖泊缓冲带泛指湖泊、水库等水体最高水位线以上的部分陆域地区,其范围根据不同水体的实际情况 有所差别. 健康完善的缓冲带应该具备以下特点: 物种丰富, 生态结构稳定, 生物多样性好, 且无明显的人为 开发建设的痕迹. 缓冲带是湖泊等水体流域生态系统的重要组成部分, 是湖泊水环境系统安全的一道至关 重要的保护屏障. 缓冲带的应用与研究在国外有较长的历史, $1960 \mathrm{~s}$ 后期, 缓冲带的概念首先在美国提出并 得以应用,认为缓冲带是将近岸区域的人类活动和水体环境有效隔绝的缓冲区域 ${ }^{[1]}$. 之后的几十年里, 欧美 等国在缓冲带植被类型及其净化效益、河湖水体缓冲带宽度确定、缓冲带管理与功能等方面开展了大量的

* 国家水体污染控制与治理科技重大专项项目 (2009ZX07101-009-001,2009ZX07106-005) 资助. $2010-08-03$ 收稿;2011-02-28 收修改稿. 胡小贞,女,1975 年生, 硕士, 副研究员;E-mail: huxz@ craes. org. cn.

** 通讯作者; E-mail:xuqj@ craes. org. cn. 
研究 ${ }^{[2-6]}$, 为缓冲带合理规划与科学布局提供了良好的数据支撑. 近年来, 随着我国湖泊保护和治理工作的 加强, 湖泊缓冲带的概念被提出, 并在缓冲带功能、构建技术等方面开展了初步的研究 ${ }^{[7-17]}$. 构建湖泊缓冲带 在我国湖泊保护与治理工作中越来越受到重视, 但如何科学定义湖泊缓冲带, 如何结合我国湖泊流域经济 发展与水污染防治工作的实际情况, 科学划定湖泊缓冲带的范围, 这方面的研究还非常欠缺. 本文以我国大 型浅水湖泊——太湖为例, 提出湖泊缓冲带的科学定义, 分析其功能, 研究缓冲带范围的科学划定方法, 在 此基础上对太湖湖泊缓冲带范围划定进行探讨, 旨在为我国湖泊缓冲带生态构建提供科学依据.

\section{1 湖泊缓冲带的科学定义及功能}

湖泊缓冲带是湖泊一定水位线之上的沿湖部分陆域地区, 通过该区域的设置, 将湖泊沿岸区域的人类 活动和水体进行有效的阻隔, 以保护湖泊水体免受污染. 缓冲带是湖泊生态系统重要组成部分, 是湖滨带外 围的保护圈, 是污染物进入湖滨带前的缓冲区域, 也是地表径流人湖前的重要屏障. 从湖泊流域保护层面来 讲, 缓冲带又是湖泊流域清水产流机制的有机组成部分, 是构成清水产流机制的三个关键环节之一, 它和湖 滨带一起发挥清水入湖前的屏障功能 ${ }^{[18]}$ (图 1).

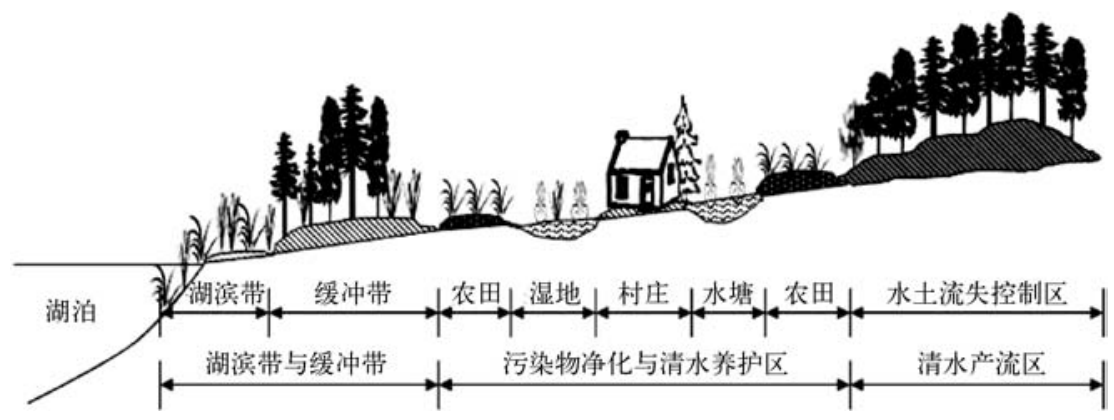

图 1 缓冲带在湖泊流域清水产流机制系统中的作用

Fig. 1 The role of buffer zone in clean water runoff generation mechanism restoration in lake watershed

综合国内外已有研究成果, 湖泊缓冲带具有如下功能: (1) 隔离和缓冲功能. 缓冲带设立后对人为活动 有一定的阻隔作用, 同时由于缓冲带设立使人类活动后退, 污染物人湖的距离变长, 起到污染物人湖前的缓 冲作用. (2) 拦截净化低污染水功能. 缓冲带内生长着大量的植被, 尤其是灌草类,其低矮、密实的特性可以 有效截留通过缓冲带的各类污染物,如有机质、氮、磷、重金属和各种离子. 植物根系能有效吸附和转化通过 缓冲带的营养物质, 减少人湖营养负荷. 因此缓冲带是控制面源污染尤其是低污染水的一道重要防线. （3）调节地表径流功能. 缓冲带内丰富的植被, 可降低地表径流的速度, 增强面源补水的下渗. (4) 保护物 种多样性. 缓冲带临近湖滨带, 植被类型多样, 可以说是重要的物种基因库之一, 它也是各种动物及鸟类的 栖息地和避难所. (5) 固岸护坡作用. 缓冲带对稳定湖泊水体岸坡, 减少土壤侵蚀有明显作用, 缓冲带内植 物可以固持土壤、减少暴雨径流的冲刷等. (6) 景观功能. 缓冲带使沿岸带生态景观得到美化, 与水体形成 完整的景观体系, 是湖泊滨岸区域的一道自然风景线. (7) 经济功能. 缓冲带内生长着较多有经济价值的动 植物种类,在其承受能力内, 可以为人类提供木材、水果、药材等植物产品,产生一定的经济效益.

\section{2 湖泊缓冲带划定的思路与方法}

\section{1 研究区域概况}

本文以太湖缓冲带的划定为例, 开展湖泊缓冲带范围划定的研究. 太湖为我国五大淡水湖之一, 位于长江三 角洲南缘. 流域面积 $36500 \mathrm{~km}^{2}$, 湖面面积 $2427.8 \mathrm{~km}^{2}$, 实际水域面积 $2338 \mathrm{~km}^{2}$, 南北长 $68.5 \mathrm{~km}$, 东西平均宽 $34 \mathrm{~km}$, 湖岸线总长 $405 \mathrm{~km}$, 平均水深 $2 \mathrm{~m}$ 左右, 总蓄水量为 $47.6 \times 10^{8} \mathrm{~m}^{3}$. 太湖流域是我国经济最为发达的地区之一.

\section{2 缓冲带划定思路与方法}

划定湖泊缓冲带包括四个步骤: (1) 资料收集. 收集缓冲带内污染源资料和已有治理工程资料, 收集流 域统计年鉴、流域相关规划、政策法规条例等基础资料. (2) 地形勘测. 采用 Leica 1230 GPS 定位、DMC 相机 
数码航摄和外业像控点测量相结合的方法, 形成 DLG 格式地形图 (比例尺 1:5000). (3) 现场调查. 基于地 形图,再通过实地考察、咨询与访谈、记录、现场测量与取样分析、影像拍摄与收集等相结合的手段,开展现 场调查. (4) 研究与分析. 基于掌握的资料与数据, 在对地形地貌、土地利用结构、人口及分布等进行综合分 析的基础上, 确定缓冲带的宽度, 划定缓冲带的边界, 基于缓冲带勘测地形图, 计算出缓冲带范围和面积. 具 体工作思路见图 2.

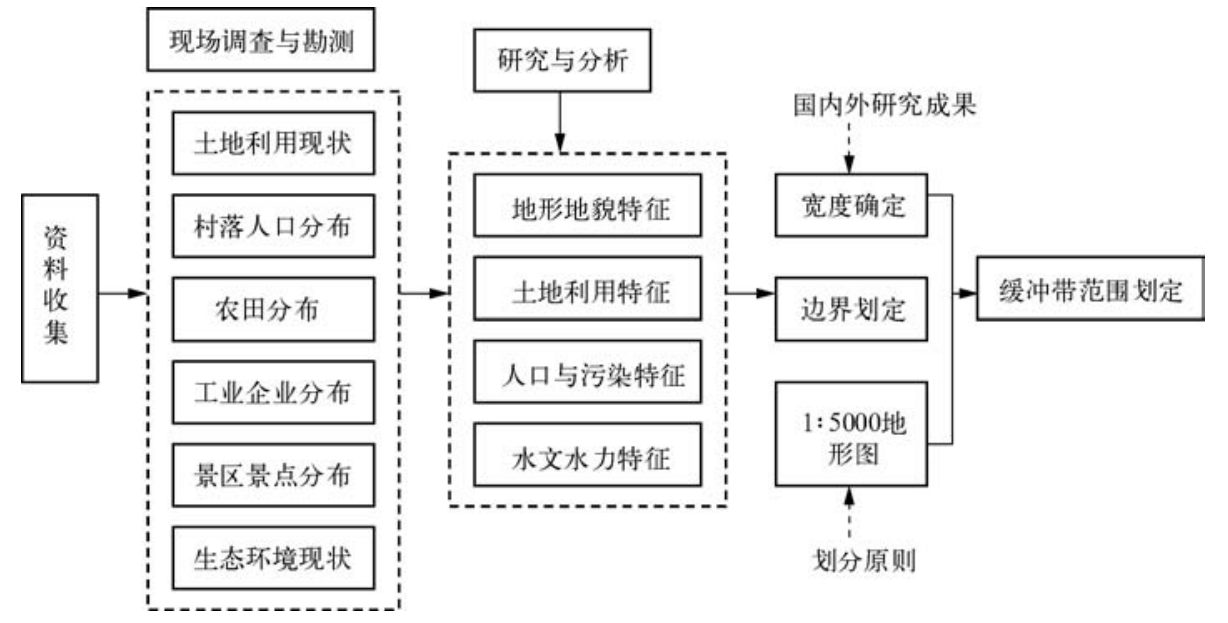

图 2 太湖缓冲带范围划定的工作思路

Fig. 2 Work mentality of Lake Taihu buffer zone delimitation

\section{3 结果与讨论}

\section{1 缓冲带宽度和上下边界的确定}

3.1 .1 缓冲带宽度的确定 我国许多湖泊均建有环湖大堤, 受环湖大堤的阻隔作用, 地表漫流的径流汇人河 流后直接人湖. 缓冲带设置后, 将有效拦截和净化这部分地表径流, 使其净化后人河人湖, 因此, 湖泊缓冲带 的建设非常重要. 但如何科学、合理地设置缓冲带仍是一个需要深人研究的问题. 尤其是缓冲带宽度的确 定, 需统筹考虑湖泊生态环境的保护和土地资源的节约, 不同类型湖泊应该结合湖泊特点因地制宜地设定.

关于湖泊缓冲带宽度的确定目前尚没有统一的方法. 欧美等国家研究结果表明, 要确定缓冲带的最小 宽度, 就必须考虑影响缓冲带功能发挥的主要变量, 这些主要变量包括: 降雨量、植被类型、土壤性质、坡度 (坡度是决定缓冲带拦蓄沉积物和滞留养分的重要变量: 坡度越小, 地表水流流速越低, 流经缓冲区的时间 越长, 污染物截留和降解效率也越高) 等 ${ }^{[19-22]}$. 综合考虑了多方面的因素, 其中水体类型、坡度、水域大小、是 否有鱼类等为影响最大的因子, 次要考虑因子包括饮用水、流域面积、毗邻森林管理、沿岸植物类型、上游水 体鱼类等, 美国及加拿大对共计 60 个 5 种类型的河湖水体缓冲带制定了平均最小的宽度 (表 1 ).

表 1 不同区域平均缓冲带宽度 $(m)^{[23] \text { * }}$

Tab. 1 Buffer widths $(\mathrm{m})$ for different waterbody types

\begin{tabular}{ccccccc}
\hline 水体类型 & $\begin{array}{c}\text { 北部区 } \\
(n=13)\end{array}$ & $\begin{array}{c}\text { 山地岩石区 } \\
(n=9)\end{array}$ & $\begin{array}{c}\text { 太平洋区 } \\
(n=6)\end{array}$ & $\begin{array}{c}\text { 东北部 } \\
(n=16)\end{array}$ & $\begin{array}{c}\text { 中西部 } \\
(n=9)\end{array}$ & $\begin{array}{c}\text { 东南部 } \\
(n=11)\end{array}$ \\
\hline 大面积常流水域 & 39.1 & 24.4 & 24.3 & 29.7 & 25.7 & 19.4 \\
小面积常流水域 & 26.3 & 24.2 & 22.7 & 23.7 & 14.4 & 17.5 \\
间歇水流 & 13.9 & 24.2 & 21.7 & 13.1 & 11.5 & 12.1 \\
小型湖泊 & 45.8 & 23.0 & 22.7 & 30.6 & 21.7 & 17.4 \\
大型湖泊 & 52.2 & 23.0 & 22.7 & 30.2 & 21.7 & 17.4 \\
\hline
\end{tabular}

*有部分河湖水体同时属于两个区域, 因此此表中 $n>60$. 
缓冲带的有效宽度是缓冲带建设与管理有效性的核心问题. 由表 1 可见, 对美国和加拿大湖泊缓冲带 宽度研究表明, 湖泊面积 $>4 \mathrm{hm}^{2}$, 坡度 $\geqslant 2.5 \%$ 的湖泊平均缓冲带宽度范围为 $17.4-52.2 \mathrm{~m}$. 从理论上而言, 缓冲带有效宽度越大, 效果就越好. 例如美国华盛顿州海岸线管理法案中规定, 位于河流 $60 \mathrm{~m}$ 范围内或 $100 \mathrm{~m}$ 以内的河漫滩以及与河流相联系的河岸都应受到保护, 而且保护的范围越大越好 ${ }^{[23]}$. 但是受土地利用的限 制, 不可能无限宽. 因此, 在缓冲带宽度确定中, 实际上是要找到一个平衡点, 既能满足水体生态保护的要 求, 又不对人类生产生活造成负面影响. 结合国内外对湖泊、河流缓冲带的界定文献资料, 充分与太湖流域 水环境综合治理总体方案中江苏省、浙江省的生态保护带、江苏省生态功能区划中禁止和限制开发区的规 定的范围相衔接 (1), 经过专家咨询与讨论, 本文确定太湖缓冲带的宽度为 $2 \mathrm{~km}$ 不等.

3.1 .2 缓冲带上下边界的划定缓冲带边界划定是缓冲带范围划定的重要内容. 由于太湖湖岸线较长, 且周 边地形与行政区域比较复杂, 明确缓冲带宽度后, 还需要根据以下三个原则确定上下边界: (1) 标识物原 则. 充分考虑太湖周边地形地貌及土地利用类型等具体情况, 以山体或公路等作为缓冲带的划分界限, 这样 将来缓冲带规划方案实施时便于识别范围. (2) 区域差异原则. 不同区域经济现状及生态环境现状不一样, 要考虑地域对缓冲带影响的区域差异性. (3) 与当地法规、条例及规划相衔接. 按照上述原则, 基于现状调 查与勘测结果, 结合当地法规、条例及规划, 确定太湖缓冲带上下边界为: 下边界的确定根据太湖实际情况, 环湖几乎都有大堤, 而且沿太湖建设的 50 年一遇的标准大堤是重要的水工建筑物, 可作为缓冲带下边界, 部分无大堤的区域则以湖岸线为下边界. 上边界的确定是以下边界线向陆地扩展 $2 \mathrm{~km}$ 为基准, 其内如有公 路或山体, 则进行相应调整, 分别以公路和山体为上边界. 如以距湖岸 $2.0 \mathrm{~km}$ 左右的行政村为上边界, 但具 体划定时注重保持行政村的完整性; 如距湖岸 1.5-2.0 km 内存在与太湖湖岸平行的公路, 则以公路作为上 边界; 如滨岸 $2.0 \mathrm{~km}$ 范围内有山体, 则以山体的山脊为上边界, 部分区域如竺山湾、梅梁湾、东诸-光福一带, 属小尺度丘岗地区, 山脊线另一侧的水也是流到太湖中, 则以山体外底线为上边界.

\section{2 太湖缓冲带范围、面积与类型}

根据上述太湖缓冲带的宽度及上下边界的划定结果, 综合考虑太湖湖边的地形、行政区划, 以及村落、 农田、工业区、景区等对太湖的影响, 基于 1:5000 地形图, 以 Auto CAD 为工具, 计算得出太湖缓冲带范围图

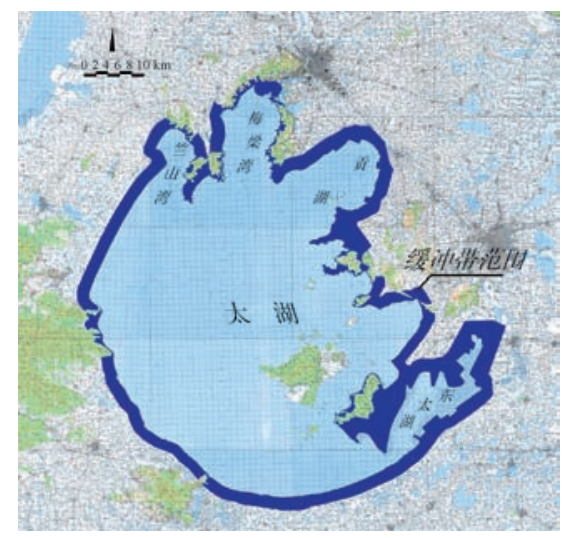

图 3 太湖缓冲带范围图

Fig. 3 Buffer zone area of Lake Taihu (图 3). 在 Auto CAD 图中, 逐片计算出缓冲带的长度和面积, 并累计加和得出缓冲带的总长度和总面积. 据计算, 太湖缓冲 带总长度为 $382.75 \mathrm{~km}$, 总面积约为 $452.31 \mathrm{~km}^{2}$ (图 3 ).

对划定的太湖缓冲带进行现状调查研究, 分析太湖缓冲带 可分为三种典型类型:

(1) 村落农田型缓冲带, 即以距湖岸 $2.0 \mathrm{~km}$ 左右的行政 村为上边界的缓冲带. 如无锡大浮镇吴塘村到苏州市望亭镇, 苏州市望亭镇到苏州市光福镇迁里村, 苏州市胥口镇马舍村到 苏州市临湖镇, 苏州市临湖镇到吴江市, 吴江市横扇镇诚心村 到湖州长兴县夹浦镇香山村, 湖州长兴县雉城镇新塘村到无锡 宜兴市新庄镇艾渎村等(图 4a).

(2) 公路型缓冲带, 即以距离湖岸 $1.5-2.0 \mathrm{~km}$ 与太湖湖 岸平行的公路为上边界的太湖缓冲带, 如宜兴新庄镇荠渎村到 周铁镇周铁村的环湖公路、宜兴周铁镇周铁村到分水村,无锡华 庄镇到苏州市高新区望亭镇的 230 省道和 312 国道等(图 4b).

（3）山体型缓冲带, 即以山体山脊作为上边界的太湖缓冲带, 主要分布于苏州光福镇安山村到苏州太 湖旅游度假区香山村, 苏州临湖镇西南的半岛地区, 浙江湖州夹浦镇香山村到宜兴丁蜀镇新园村, 宜兴周铁 镇分水村到常州市雪堰镇太滆村, 无锡马山半岛的临湖山地, 常州市雪堰镇到无锡大浮镇的大浮村等区域 (图 4c).

(1) 无锡规划局. 无锡市太湖一级保护区保护建设规划公示, 2007 . 
本文在太湖缓冲带宽度确定时, 以国外水体缓冲带最小 宽度的研究为参考, 充分考虑了太湖湖泊社会经济现状与水 污染特征, 针对太湖实际情况确定缓冲带的合理 (或工作) 宽 度, 与欧美等国缓冲带最小宽度的范围有一定区别. 划定的 太湖缓冲带范围, 按照缓冲带离湖的远近, 又可具体划分成 内圈生态保护区和外圈限制开发区两大部分. 初步确定为大 堤向外 50-200 $\mathrm{m}$ 不等的范围, 为内圈生态保护区的范围, 此 范围与国外水体缓冲带最小宽度的范围基本一致,该区域应 统筹考虑太湖地区土地利用、经济发展与环境保护情况,清 除人为干扰, 建设环湖生态防护林带. 拟定内圈生态保护区 以外的 200-2000 $\mathrm{m}$ 不等的范围为外圈限制开发区, 区内进 行污染综合治理和绿色、循环经济的建设, 构建成环湖绿色 经济带. 当然, 太湖湖泊缓冲带的设置和生态建设实践还有 相当长一段路要走, 它涉及到区域生态环境保护、地方经济 发展以及社会安定等诸多方面, 必须与国家中长期水污染治 理战略和地方规划紧密结合,分批分阶段地逐步实现.

\section{4 结论}

湖泊缓冲带的划定和应用对于我国大型浅水湖泊水体 污染控制与生态修复具有十分重要的意义. 缓冲带保护与生 态恢复间接反映并具体化了土地利用保护与湖泊环境质量 改善的关系, 可以说它是土地科学与生态学向土地利用实践 方向发展的一项实用型工程技术概念与措施. 如何科学划定 湖泊缓冲带的范围是湖泊缓冲带生态保护与修复首要解决

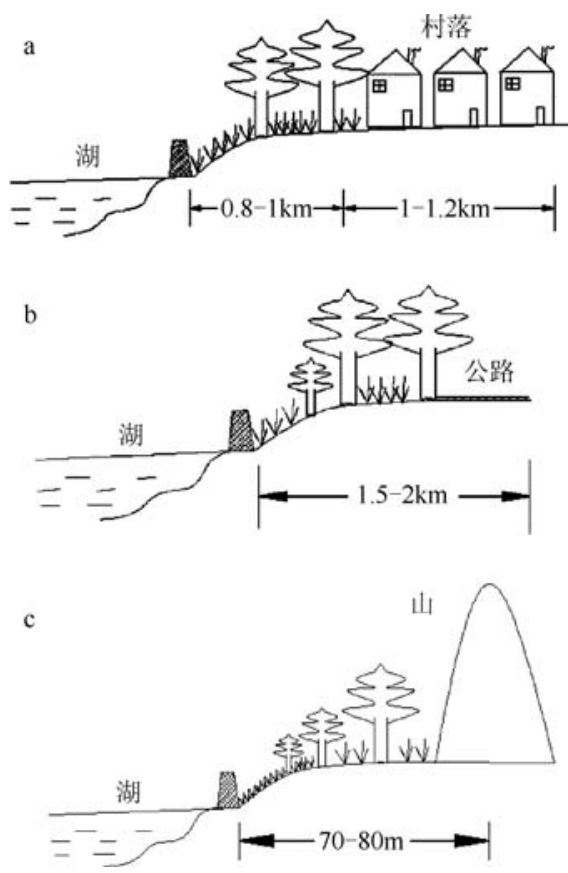

图 4 太湖农田村落型 (a)、公路型 (b) 和山体型 $(\mathrm{c})$ 缓冲带剖面示意图

Fig. 4 Schematic profile for farmland and villages type(a), road type(b) and mountain type(c) buffer zones of Lake Taihu 的问题. 本文采用文献调研、地形勘测、现状调查,结合湖泊 流域土地利用、经济发展与湖泊流域保护等诸多方面进行研究分析, 并咨询专家进行讨论, 初步提出了太湖 缓冲带的工作定义与范围. 确定太湖缓冲带的宽度为 $2 \mathrm{~km}$ 不等, 缓冲带以沿太湖建设的 50 年一遇的标准大 堤或湖岸线为下边界, 以下边界线向陆地扩展 $2 \mathrm{~km}$ 不等为基准, 考虑标识物 (村落、山体、公路) 及区域差异 等原则, 确定缓冲带的上边界; 基于 1:5000 地形图, 以 Auto CAD 为工具, 计算得出太湖缓冲带总长度为 $382.75 \mathrm{~km}$,总面积约为 $452.31 \mathrm{~km}^{2}$; 太湖缓冲带可分为村落农田型、公路型、山体型三种典型类型. 然而, 所 划定的缓冲带正位于 “太湖水污染防治条例”划定的一级保护区境内, 缓冲带的功能如何与一级保护区的空 间管理相协调, 是未来值得进一步研究的方面. 另外, 如何应用模型和模拟研究, 从缓冲带宽度与污染物削 减效果的关系方面来更加地科学地定义我国湖泊最适缓冲带的范围, 也还待进一步深人研究.

\section{5 参考文献}

[ 1 ] 史志刚. 美国的水土保持与植物缓冲带技术. 江淮水利科技, 2006，(6)：5-6.

[ 2 ] Barfield BJ, Blevins RL, Fogle AW et al. Water quality impacts of natural filter strips in karst areas. Transactions of the American Society of Agricultural Engineers, 1998, 41(2) : 371-381.

[ 3 ] Bavor HJ, Roser DJ, Adcock PW. Challenges for the development of advanced constructed wetlands technology. Water Science and Technology, 1995, 32(3) : 13-20.

[ 4 ] Anna L, Bradley L, Ross G. Bat activity on riparian zones and upper slopes in Australian timber production forests and the effectiveness of riparian buffers. Biological Conservation, 2006, 129: 207-220.

[ 5 ] Schoonover JE, Williard KWJ, Zaczek JJ. Nutrient attenuation in agricultural surface runoff by riparian buffer zones in Southern Illinois, USA. Agroforestry Systems, 2005, 64: 169-180.

[ 6 ] Lowrance R, McIntyre S, Lance C. Erosion and deposition in a field/forest system estimated using cesium-137 activity. 
Journal of Soil and Water Conservation, 1988, 43 : 195-199.

[ 7 ] 张建春, 彭补拙. 河流带研究及其退化的生态系统恢复与重建. 生态学报, 2003, 23 (1): 56-63.

[8] 邓红兵, 王青春, 王庆礼等. 河岸植被缓冲带与河岸带管理. 应用生态学报, 2001, 12(6): 951-954.

[9] 李世锋. 关于河岸缓冲带拦截泥沙和养分效果的研究. 水土保持科技情报, 2003，(6): 41-43.

[10］李同杰, 刘晶晶. 条状草地、农林缓冲系统对土壤理化性质的影响. 水土保持科技情报, 2005, (6): 23-25.

[11］陈小华, 李小平. 河道生态护坡关键技术及其生态功能. 生态学报, 2007, 27(3): 1168-1175.

[12］许朋柱，秦伯强. 太湖湖滨带生态系统退化原因以及恢复与重建设想. 水资源保护, 2002，(3) : 31-36.

[13] 王东胜, 朱 瑶. 岸边缓冲带生态功能及其建设的理论. 水力学与水利信息学进展, 2007: 472-476.

[14] 罗晓娟, 余勇利. 植被缓冲带结构与功能对水质的影响. 水土保持应用技术, 2006, (4): 1-3.

[15] 朱季文, 季子修, 蒋自巽. 太湖湖滨带的生态建设. 湖泊科学, 2002, 14(1): 77-82.

[16] 吴建强, 黄沈发, 吴 健等. 缓冲带径流污染物净化效果研究及其与草皮生物量的相关性. 湖泊科学, 2008, 20 (6) : 761-765.

[17］颜昌宙，金相灿，赵景柱等. 湖滨带的功能及其管理. 生态环境, 2005, 14(2) : 294-298.

[18］金相灿, 胡小贞. 湖泊流域清水产流机制修复方法及其修复策略. 中国环境科学, 2010, 30(3) : 374-379.

［19］诸葛亦斯，刘德富，黄钰铃. 生态河流缓冲带构建技术初探. 水资源与水工程学报, 2006, 2(17): 63-67.

[ 20 ] Palone RS, Todd AH. Chesapeake Bay riparian handbook: a guide for establishing and maintaining riparian forest buffers. USDA Forest Service NA-TP-02-97, 1997.

[21] Sehueler T. The stream protection approach. Washington DC: Center for Watershed Protection, Terrene Institute, 1994.

[22] 席北斗, 于会涁, 马文超等. 湖岸缓冲带反硝化作用的研究进展. 环境工程学报, 2009, 3(10): 1729-1733.

[23] Lee P, Smyth C, Boutin S. Quantitative review of riparian buffer width guidelines from Canada and the United States. Journal of Environmental Management, 2004, 70 : 165-180. 